\section{International Scientific Journal Theoretical \& Applied Science}

p-ISSN: 2308-4944 (print) e-ISSN: 2409-0085 (online)

Year: $2014 \quad$ Issue: $10 \quad$ Volume: 18
Galiya Koyanbaevna Bizhanova docent, Senior Lecturer of the Department of Pedagogics and Psychology, Arkalyk State Pedagogical Institute named after I.Altynsarin, Kazakhstan Galia_arka@mail.ru

SECTION 21. Pedagogy. Psychology. Innovations in the field of education.

\title{
SYSTEMS OF EDUCATION IBRAI ALTYNSARIN
}

\author{
Abstract: The given article considers actual problems and role of education systems Ibrai Altynsarin in \\ education of Kazakhstan. \\ Key words: school, system, Kazakhstan. \\ Language: English Russian \\ Citation: Bizhanova GK (2014) SYSTEMS OF EDUCATION IBRAI ALTYNSARIN. ISJ Theoretical \& \\ Applied Science 10 (18): 88-90. doi: http://dx.doi.org/10.15863/TAS.2014.10.18.19
}

\section{СИСТЕМЫ ОБУЧЕНИЯ ЫБЫРАЙ АЛТЫНСАРИНА}

Аннотация: В данной статье рассматриваются актуальные проблемы и роль учебной системы Ы. Алтынсарина для образования Казахстана.

Ключевые слова: школа, система, Казахстан.

Современный период развития общества характеризуется все большим нарастанием внимания общественности к научно педагогической теории и практике. Инновационные процессы в образовании являются неотъемлимой чертой нашего времени [1]. Инновации не создаются на пустом месте. В педагогической науке накопилось немало фундаментальных теорий, освоение которых в современных условиях создают плодородную почву для педагогического творчества и воссоздания педагогами инновационных технологий. Поэтому начинающим педагогам необходимо ориентироваться на основные постулаты в тех или иных методологических конструкциях, чтобы на их основе создавать собственные технологии.

В данной статье нами предпринята попытка установления связи педагогических идей и современных инновационных технологий в их исторической динамике, на примере педагогических идей Ы.Алтынсарина.

8 января 1864 г. в присутствии более 200 ордынцев и всех присутствующих господ офицеров торжественно была открыта школа, которая положила начало светского образования в Казахстане [2, с.15]. В период подготовки к строительству и открытию школы, за два года Ы.Алтынсарин обучил 4-х мальчиков у себя на дому, которые впоследствии стали его помощниками в организации обучения.

Начальник Оренбургского укрепления, переименованного впоследствии в г. Торгай, 22 января 1864 г., сообщал Оренбургскому и Самарскому генерал - губернатору, что «открытие школы ордынцами встречена с непритворной радостью и благодарностью»[3, с.12].

Он высоко отозвался об учителе этой школы Ы.Алтынсарине, а также об успехах учащихся, как результата целостности и системности процесса взаимообучения детей.

Заслуга великого казахского просветителя Ы.Алтынсарина была в том, что он пересмотрел факторы, влияющие на систему образования: возможности учительских кадров, сформированность самосознания и др., что привело к необходимости пересмотра и введения той системы, которая была к этому времени аппробирована в странах Западной Европы и России - Белль - Ланкастерской[4,с.21].

Известно, что еще в 1790 г. священник А.Белль, преподавая в Мадрасе в военносиротском училище, руководствовался этим методом. Сначала учеников у него было около 100 , а чуть позже уже около 200. Это неимоверно затрудняло процесс обучения. А.Белль подготовил несколько наиболее способных учеников, которым поручил обучать 
безграмотных. Эти помощники стали называться мониторами.

Эта система была усовершенствована И.Ланкастером для обучения бедных[5,c.27]. Были введены таблицы с крупно напечатанными словами, слогами, фразами и аспидные доски. Так возникла Белль-Ланкастерская система взаимного обучения.

В 1817 г. по приглашению графа Н.П.Румянцева из Лондона в Могилевскую губернию, г. Гомель прибыл молодой педагог Яков Гердт (1799-1875), для открытия первого в России училища трудолюбия и взаимного обучения. Это послужило началом широкого применения в России метода взаимного обучения[6,c.35].

Прежде всего, хороша она была тем, что в финансовом отношении оказалась мало затратной - один учитель с ее помощью мог обучать 200 и более учеников.

Сущность метода состоит в следующем:

1. Ученики, добившиеся очевидных успехов передают свои знамения менее успевающим;

2. Внимание и активная деятельность учеников поддерживается благодаря атмосфере соревнования;

3. Весь процесс обучения основан на правилах порядка и соподчиненности;

4. Вместо книг употребляются таблицы, аспидные доски;

5. Каждое дитя помещается в то отделение учеников, в котором состоят равные ему по степени познания, а перевод в другое отделение производится исходя из достигнутых им успехов[7,c.115].

В последние годы наступает длительный промежуток времени, в котором происходит спад интереса к Белль - Ланкастерскому методу. Но в начале XX века в России вновь просыпается интерес к системе взаимного обучения. Автором обновленного подхода стал А.Г.Ривин, который стал называть свою систему методом талгенизма (талант и гений). В 1950г. идея взаимного обучения вновь пробивает себе дорогу и возрождается в работах В.В.Дьяченко и его последователей[8,c.214].

Технология коллективного взаимообучения А.Г.Ривина и его учеников по философским основам относится к неоэкзистенциалистической. Она - одна из популярных личностноориентированных технологии обучения. Методики А.Г.Ривина имеют различные названия: «организованный диалог», «сочитательный диалог», «коллективные взаимообучения», «коллективный способ обучения», «работа учащихся в парах сменного состава»[9,с.76].

Обучение в сотрудничестве организационная форма, при которой весь класс делится на малые группы в них учитель организовывает взаимодействия обеспечивая равные возможности для успеха и помощи каждого члена команды друг другу. В итоге в группе формируется групповые цели, призванные обеспечить успех всей группы, а учитель выступает в роли организатора самостоятельной познавательной деятельности учащихся.

В современной практике существует и иные формы организации обучения. Например, на западе имеется неградированные классы, когда ученик по одному предмету может обучатся по программе 7 класс, а по другому «быть в 5 классе». Существует и такая форма организации обучения, как «погружение», когда на протяжении нескольких дней учащиеся осваивают только один или два предмета. Аналогично организуется обучение по эпохам в Вальдорвских школах.

Урок как основная форма органично дополняется другими формами организаций учебно-воспитательного процесса. Часть из них развивалась параллельно с уроками, т.е. в рамках классно-урочной системы, другие заимствованы из лекционно-семинарской системы и адаптированы с учетом возраста учащихся.

В современном Казахстане, когда около половины составляют малокомплектные школы с совмещенными классами обучения система заложенная Ы.Алтынсариным во второй половине XIX в. Могла бы успешно применяться и в XXI в.

Анализ Государственного стандарта образования начальной школы по предмету казахского языка показывает соответствие количество часов и срока их прохождения во 2-х и 4-х классах, что дает возможность их не только совместно обучать, но и взаимообучать.

Например, тема «Предложения и их виды». Учащиеся делятся на группы. Ученикам 4-х классов дается возможность вспомнить и повторить материал по теме за 2 класс. Затем, совместить всех учащихся, создать смешанные группы из учащихся 2-х и 4-х классов, назначить мониторов, из учащихся 4-х классов. Они разъясняют, опрашивают, натаскивают учащихся 2-х классов. Следующий этап: учитель проводит отдельно занятия с учениками 4-х классов для более углубленного изучения соответственно требованиям класса.

Контроль и проверка знаний по всему сводному классу проводится по степени сложности. В данном примере применяется коллективный способ обучения (КСО) включение в учебный процесс общения между людьми - диалогические пары. Для КСО характерно завершенность, или ориентация на высшие конечные результаты, непрерывная безотлагательная передача полученных знаний друг другу, сотрудничество и взаимопомощь между учениками; разделение труда, 
разноуровневость, разновозрастность учеников в педагогическом процессе; обучение по способностям индивида; педагогизация деятельности каждого ученика[10,с.15].

Результаты экспериментальной работы в начальных классах малокомплектных школ Торгайского региона показывает преимущества коллективного способа взаимообучения:

- в результате регулярно повторяющихся упражнений совершенствуются навыки логического мышления и понимания;

- в процессе речи развиваются навыки мыследеятельности, включается работа памяти, идет мобилизация и актуализация предшествующего опыта и знаний;

- каждый чувствует себя раскованно, работает в индивидуальном темпе;

- повышается ответственность не только за свои успехи, но и за результаты коллективного труда;
- отпадает необходимость в сдерживании темпа продвижения от них и в понукании других учащихся, что позитивно сказывается на микроклимате в коллективе;

- формируется адекватная самооценка личности, своих возможностей и способностей, достоинств и ограничений;

- обсуждение одной информации с несколькими сменными партнерами увеличивает число ассоциативных связей, а, следовательно, обеспечивает более прочное усвоение.

Таким образом, мы исходим из понимания инновационной образовательной технологии как некоторой алгоритмической конструкции имеющую прочную методологическую основу и историческую связь времен.

\section{References:}

1. (2007) Zakon «Ob Obrazovnaiya» Respubliki Kazakhstan.

2. Ilminskiy NI (1891) Vospominanie ob Altynsarine. Kazan, pp.15.

3. Tazhibaev TT (1962) Poseshchenie i shkoly Kazakhstana vo vtoroy polovine XIX v. Almaata, pp.12.

4. Polyanskiy VS (2001) Teoreticheskie osnovy psikhologo-pedagogicheskogo soprovozhdeniya obuchaemykh. Innovatsii v obrazovanii. No. 3, pp. 21.

5. Podlasyy IP (1996) Pedagogika: Uchebnoe posobie dlya studentov vysshikh uchebnykh zavedeniy. Moscow, pp.27.
6. Moreva NA (2001) Pedagogika srednego professional'nogo obrazovaniya: Ucheb. posobie dlya studentov vyssh. ped. ucheb, zavedeniy. Moscow: Akademiya, pp.35.

7. Teleshov SV (2005) Lankasterskaya shkola v Rossii. Pedagogika. No.10, pp.115.

8. Busse FI (1829) Rukovodstvo k uchrezhdeniyu shkol po metode vzaimnogo obucheniya. SPB, pp. 214.

9. Bortko TG (2008) Innovatsionnye obrazovatel'nye tekhnologii. Uch. Posobie. Kostanay: KGU im. A.Baytursynova, pp.76.

10. Nesterenko AA (2000) Strana zagadok. Shkol'nye tekhnologii, No.5, pp.15. 